\title{
A Research on the Professional Future Expectations of the Students of the German Language Teaching Department
}

\author{
Orhan Bozdemir \\ Correspondence: Orhan Bozdemir, Ataturk University, Kazım Karabekir Faculty of Education, Department of Foreign \\ Language Education, Department of German Language Education, 25240 Erzurum/Turkey.
}

Received: Feb. 2, 2020

doi:10.11114/jets.v8i5.4702
Accepted: Mar. 9, 2020

Online Published: Mar. 12, 2020

URL: https://doi.org/10.11114/jets.v8i5.4702

\begin{abstract}
This is a qualitative study that aims to shed light on the opinions of the students of German Language Teaching Department about their professional future, the level of their expectations of being appointed as a teacher, and what alternative options they are considering in case they are not appointed. A survey study, which is one of the qualitative research techniques, was used in the research. The survey questions were asked to the participants about their professional future expectations and participants were asked to score their expectations from 1 to 5 . Likert type "Professional Expectation Scale" was developed for the research. The results revealed that the students wanted to work as German teachers and do not intend to employee other jobs far from their professional fields. However, they are desperate about working in their field in the public. Also, the future expectation levels of second, third and fourth (last) year students were obtained quite similar. In addition, it was found to have an equal distribution of different opinions for living in a German-speaking country in the later period of their life.
\end{abstract}

Keywords: German language teaching, student's future expectation, likert-type rating scales

\section{Introduction}

A profession is an ongoing effort not only to meet economic needs, but also to provide the individual psycho-social development and satisfaction (Yazici, 2009). Understanding the factors that lead to academic success is one of the popular areas of research today (Johnston, 2003). The increase in the number of students in higher education brings with it a decrease in the employment of graduates. The challenge of universities is motivating the students to academic success under difficult employment conditions. (McKenzie \& Schweitzer, 2001). Especially future perspectives of students of education faculties are important, because of the quality of education and manpower in a country is considered and evaluated together with the quality of its teachers (Sezgin \& Duran, 2011). Yet, our inability to predict the future is one of the main causes of stress (Cuceloglu, 1999). On the other hand, stress often appears as a factor that affects success and failure. Individuals who are not sufficient in terms of knowledge, who have inadequate experience and who do not or cannot adequately prepare worry more about their jobs. In some cases, this stress progresses so much that it progresses to the stage of fear and causes discouragement in the individual (Bozdam, 2008).

The results obtained in many studies in worldwide on this subject show that there is a significant relationship between the university students' attitudes towards the future, their positive future expectations and their psychological well-being and that positive future expectations affect their psychological well-being more than their attitude towards the future (Ehtiyar, 2017) (Gustems-Carnicera et al., 2013) (Wang et al., 2007) (Washizu \& Naito, 2015). In one study, it was determined that prospective teachers' expectations for the future are not very negative, but some prospective teachers have intense level of despair (Ceyhan, 2004).

Today, teaching German as a foreign language is carried out in line with communicative and intercultural approaches. The acquisition and development of listening, speaking, reading, writing skills and cross-cultural emotional skills for foreign language use are among the primary objectives of foreign language courses (Cetintas \& Genc, 2005). However, it cannot be denied that this is also related to the German Teaching employment. It is known that the German language departments are one of the fields in which the least number of teachers are employed in Turkey. For example, between 2011-2012 only 73, between 2012 - 2013 only 420, between 2013 - 2014 254, between 2014 - 2015 195, and between 2015 - 2016210 German teachers were employed (Yucel \& Gocerler, 2018). However, there are 18 German Language Teaching Departments within the Faculties of Education in Turkey. These departments accept about 50-60 students each 
year and approximately 300-400 students study in each department. The number of students who graduate each year is around 1000. Nonetheless, graduates of the Department of German Language and Literature and German Translation and Interpreting, who obtained the right to teach by benefiting from pedagogy certificate programs, double this number.

Graduates from the Department of German Language and Education work in schools connected to the Ministry of National Education, private schools, private language courses, hotels, restaurants, travel agencies and airports, and of course in universities in the forms mentioned above. In addition, a university graduate with a foreign language and a pedagogy certificate can find jobs in various positions in public and private institutions, albeit limited (Polat, 2013). Our study aims to determine the ideas of the students of the German language teaching departments regarding their professional future expectations. In this context, it is thought that employment strategies in national education can be restructured from the perspective of future prospective teachers.

\section{Method}

\subsection{Participants}

The sample of the study was drawn from a medium-sized public university in Turkey. The participants of the research consisted a total of 130 students who have reached B1 level in German education in the German teaching department of a public university as of 2018-2019 academic year (they were completed the primary learning class and 1st grade education).The group of participants 42, 55 and 33 were second, third and fourth (last) year students, respectively. Students were asked to participate in this study voluntarily. The results of the survey were interpreted through graphics and they were only prepared for use in present study.

\subsection{Materials}

Prior to quantitative data gathering, personal interviews were carried out with 10 students to obtain better understanding of the topic under study. They were asked to explain their degree of study motivation and factors affecting their academic success. Afterwards, the preliminary version of the questionnaire was tested on a small sample of students to eliminate ambiguous materials. The questionnaire consisted of 5-point Likert-type rating scales $(1=$ strongly disagree to $5=$ strongly agree).

\subsection{Data Analysis}

The data sheet was exported into Excel 2010 (Microsoft) for analysis. The categorization was done by inspection by one researcher after carefully reading and recording a modified list of categories. Percentage values of the answers received from the participants were determined by the mean and standard deviation values. In order to understand whether there is a difference between the three classes participating in the study in terms of the future perspective, a scoring system created from the survey questions was used for determination of general awareness level of the participants according to the years they are studying (Table 1).

\section{Results and Discussion}

Table 1 shows the preliminary questions that asked to participant obtaining for their awareness of the future perspective. It was seen that the awareness levels of the students' expectations for the future in the second, third and fourth grades were very close to each other.

Table 1. Preliminary questions for awareness of the future carrier perspective of participants. Participants were asked to give a score between 0 and 5 for each question. Mean values and standard deviations were determined for each class

\begin{tabular}{|c|c|c|c|}
\hline \multirow{2}{*}{ Questions (0-5 points) } & \multicolumn{3}{|c|}{ Mean Scores and Standard Deviations } \\
\hline & 2nd & 3th & 4th \\
\hline Did you decide what you want to do after graduation? & $3.11 \pm 0.15$ & $3.21 \pm 0.45$ & $3.35 \pm 0.15$ \\
\hline $\begin{array}{l}\text { Do you know about the possibility of working as a } \\
\text { German teacher? }\end{array}$ & $2.52 \pm 0.63$ & $2.72 \pm 1.15$ & $2.38 \pm 0.09$ \\
\hline $\begin{array}{l}\text { Do you know how many of graduated person of this } \\
\text { program before work as a German teacher? }\end{array}$ & $1.82 \pm 1.26$ & $1.56 \pm 0.23$ & $1.75 \pm 0.21$ \\
\hline $\begin{array}{l}\text { Do you know how much salary teachers of German } \\
\text { language teachers get paid? }\end{array}$ & $2.65 \pm 0.95$ & $2.95 \pm 0.36$ & $2.75 \pm 1.35$ \\
\hline $\begin{array}{l}\text { Do you know about the possibility of working and } \\
\text { living in Germany }\end{array}$ & $1.12 \pm 1.32$ & $1.32 \pm 1,24$ & $1.08 \pm 0.16$ \\
\hline
\end{tabular}


The answers given by the students of the German Education Departments to the question about being appointed as a German teacher point out that they are not hopeful in this regard. Only 19\% of participants sure of that and $19 \%$ of them will be appointed as German teachers with uttermost confidence, 5\% of them feel very desperate. As expected, about half of the participants (41\%) of them were stated that they are "not sure" (Fig. 1). Since most probably they observe their friends who graduated before them very well, participants think that they can work as a German teacher in "private schools", $8 \%$ of them are negative towards this possibility, of which only $2 \%$ are certain, the rate of those who are indecisive in this matter is only $16 \%$ (Fig. 2).

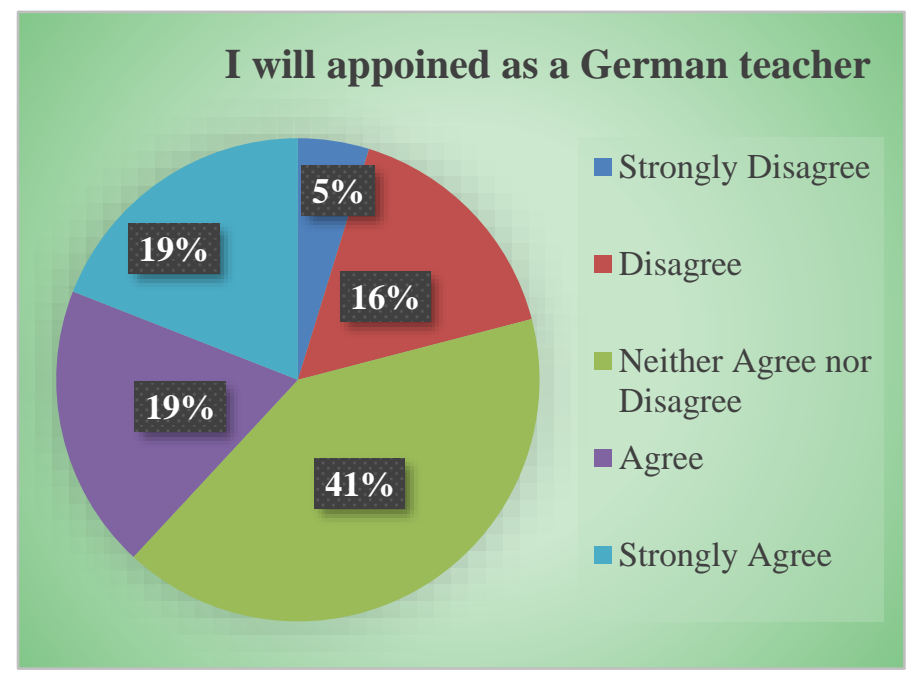

Figure 1. Our students' ideas about being appointed as a German teacher

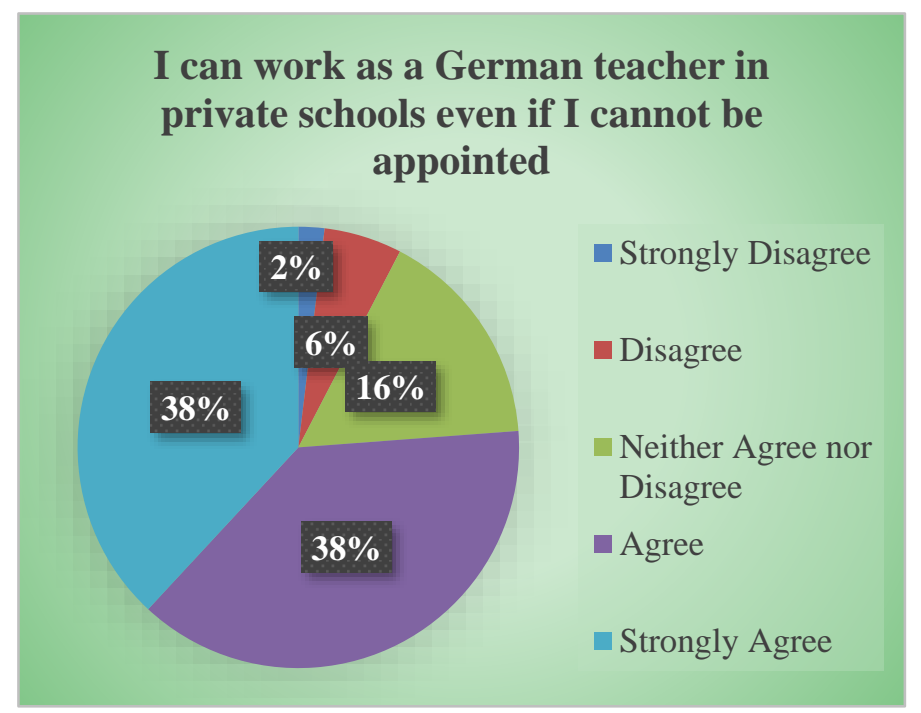

Figure 2. Our students' opinions about teaching in private schools

As for the establishing their own business, $43 \%$ of participants think negatively, while $21 \%$ are undecided about it, only $11 \%$ think that they can start their own business, of which $9 \%$ is extremely confident. It is seen that they approach the idea of living in a German-speaking country more positively (Fig. 3). As 9\% of our students are extremely sure, for totally $36 \%$ it seems possible; as it is impossible for $43 \%$ and $16 \%$ are undecided about it. 


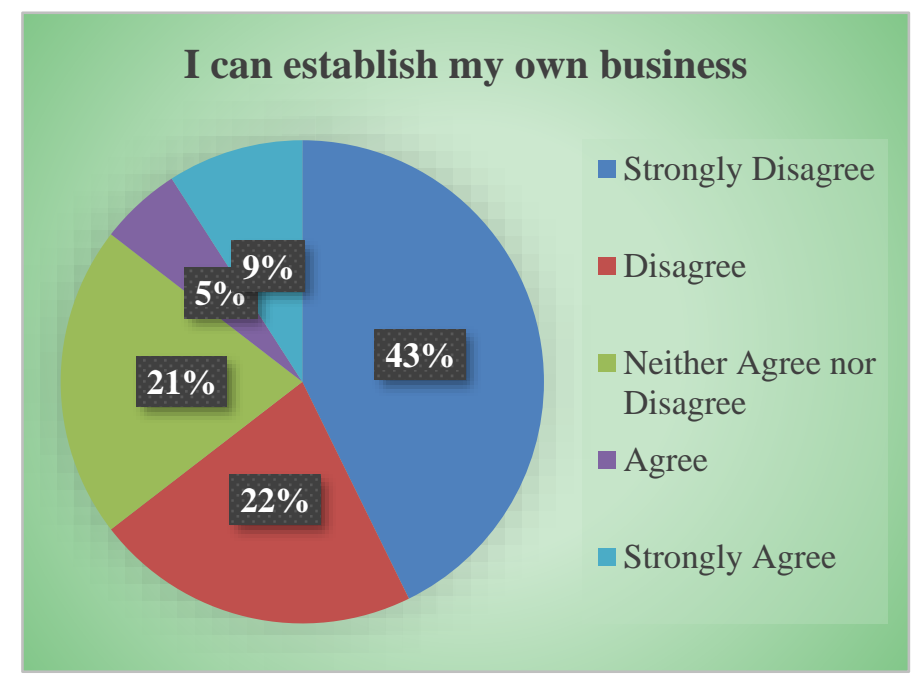

Figure 3. Our students' ideas about working by establishing their own businesses

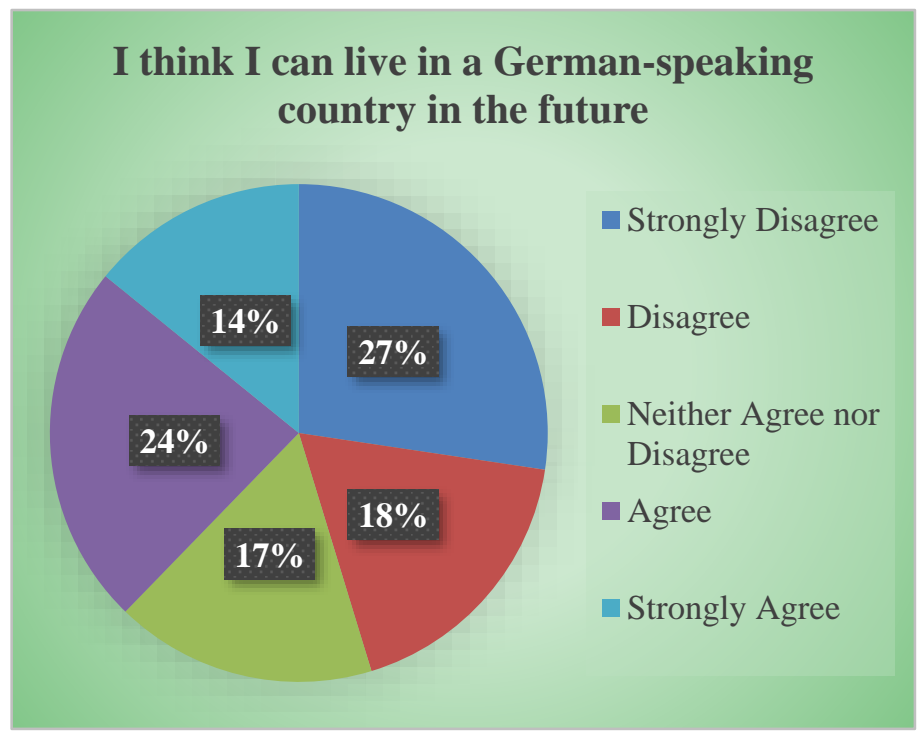

Figure 4. Our students' ideas about living in a German-speaking country

The survey results support the idea that the general concern for the future of the students of education faculties in Turkey leads them to postpone this subject to after graduation and makes it difficult for them to concentrate on their educational life. A total of $54 \%$ students, as $38 \%$ of them for certain, refuse to postpone thinking about job opportunities after graduation, a total of $31 \%$, as $16 \%$ of whom for certain, that is about $1 / 3$ of them, agree, and the rate of those who are not sure is $15 \%$ (Fig. 5). A similar situation applies to the possibility of finding a job as a university graduate at another institution. The rate of students who think they can find a job as a university graduate as academician, military officer, police officer, banker etc. in any institution is $45 \%$ in total, $22 \%$ of whom are very confident. The rate of those who ignore this possibility is $19 \%$, of which $11 \%$ are certain. The rate of those who are not sure about this is very high with $36 \%$. 


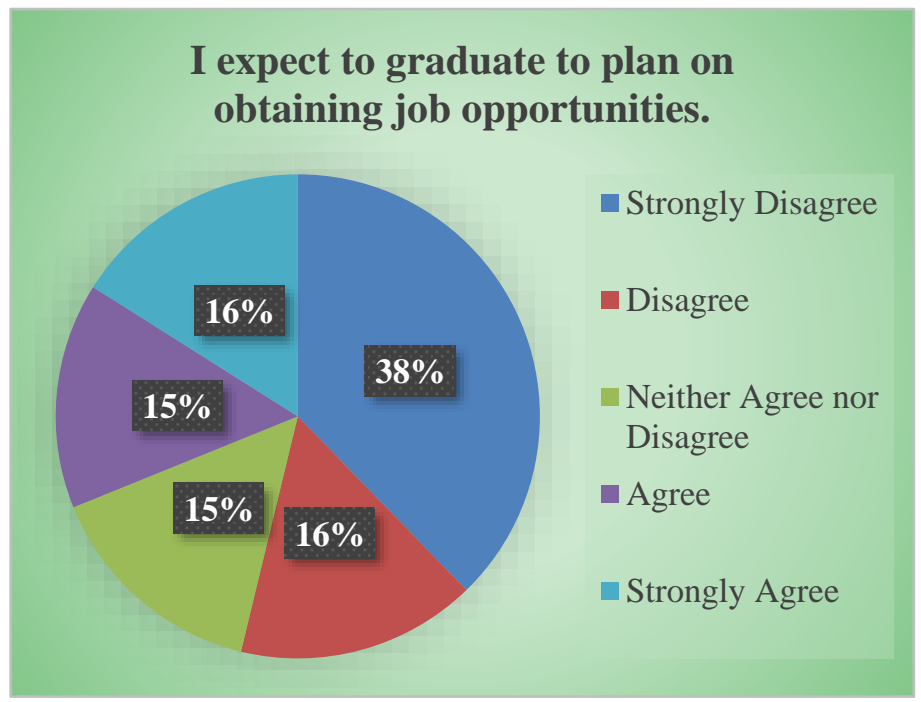

Figure 5. The interest level of our students about obtaining job opportunities

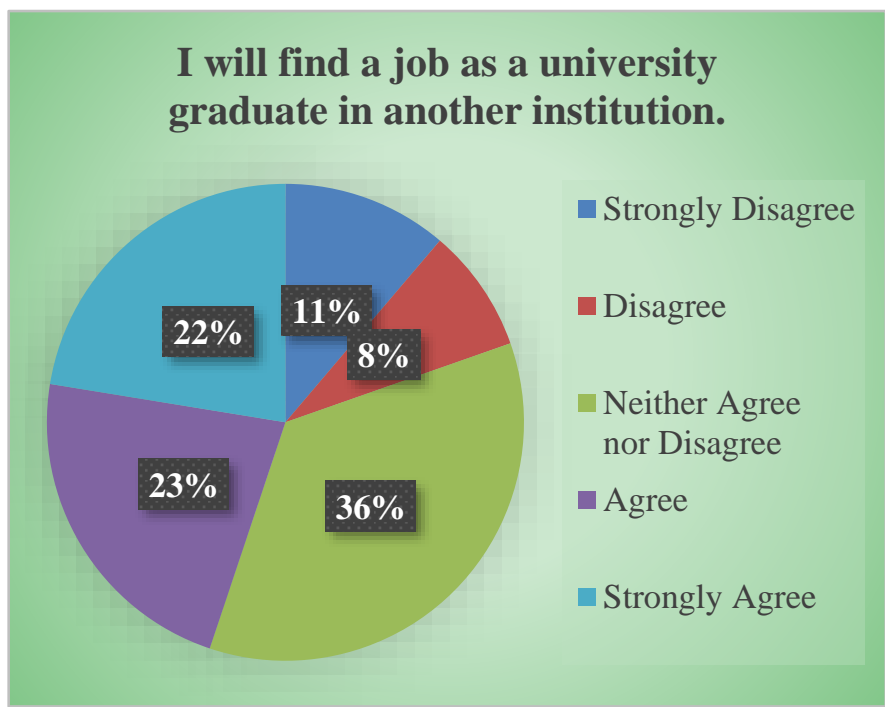

Figure 6. Our students' opinions about working in another public institution

The results of a study carried out in Germany are surprisingly similar to our students' expectations. In this research, which has followed the professional lives of students after graduation who graduated from the German Language Departments as foreign language which we can accept as the equivalent of the German Language Teaching Department as (Daf) in Germany, it has been observed that the majority of graduates work in exchange for course fee as in Turkey; and the study, in which 167 students were monitored, also shows that 58 students work in private language schools, colleges and various organizations for a course fee. The second largest group consists of 51 students, 20 of whom are research assistants in colleges, who have settled in institutions as contracted officers. The number of unemployed people after graduation is 27 . The next group of 20 people has chosen to pursue university education in a number of temporary activities with the scholarships of various institutions such as the German Academic Exchange Service (DAAD), and 14 students have chosen to continue their university education in another department. Apart from working as contracted officers and in return for course fees, the number of independent employees is 13 , and whereas there are 12 people doing their $\mathrm{PhD}$ in the sixth place, they are followed by 11 people who are hired as teachers and those who are currently interns. While 9 people declared that they attended various courses, 2 people said they were housewives or men (Hunstiger \& Koreik, 2006).

The income status of graduates of German Language Teaching Departments in Germany also surprisingly shows similarities with their colleagues in Turkey. According to the Geva Institute data; graduates who earn approximately 16,250 Euros per year including holiday bonuses and holiday allowance earn less than half of what other university graduates earn for example, such as IT (39,750 Euros), Natural Sciences (37,950 Euros), Business, Economics (36,260 Euros), Social Sciences (34,520 Euros) (Hunstiger \& Koreik, 2006). 


\section{Conclusion}

Students' future expectations and concerns affect both their mental states, their daily lives and, of course, their school success (Wang et al., 2007) (Washizu \& Naito, 2015). We think that the study we carried out in order to better understand our students and reveal the opinions of the students of German Language Teaching Department about their professional future, the level of their expectations of being appointed as a teacher, and what options they think are possible if they cannot be appointed shows a clear and thought-provoking image. Insufficiency in the appointment of German Language teachers negatively affects students' professional concerns.

When compared the future expectation level of the three subclasses included in the study, the fact that there is no significant difference between them. This finding shows that the future expectation does not take shape as expected as by years during the graduation program. However, in general, students' career goals are expected to develop and shape throughout university life (Monks, Conway, \& Dhuigneain, 2006).

We think that simple measures such as the creation of elective courses suitable for students ' possible career planning and the selection of course content as much as possible in relation to these expectations will make it easier for students to shape their future prospects with a broader perspective within the education system.

\section{References}

Argon, T., \& Eren, A. (2004). Human Resources Management, ( $2^{\text {nd }}$ Ed), Nobel Yayın Dağıtım, Turkey.

Ataturk, M. K. (1945). Ataturk's discourses and statements, Atatürk Araştırma Merkezi, Turkey.

Atmaca, H. (2013). Professional Concerns of Prospective Teachers Studying in German, French and English Teaching Departments. Electronic Turkish Studies, 8(10), 67-76. https://doi.org/10.7827/TurkishStudies.5907

Bozdam, A. (2008). Examining the professional anxiety levels of prospective teachers in terms of some variables, Selçuk University Institute of Health Sciences, Konya, Turkey

Buyukozturk, S., Cakmak, E. K., Akgun, O. E., Karadeniz, S., \& Demirel, F. (2017). Scientific Research Methods. Pegem Citation Index: 1-360. https://doi.org/10.14527/9789944919289

Cakmak, O., \& Hevedanli, M. (2005). Investigation of Anxiety Levels of Students of Faculty of Education and Science and Letters, Department of Biology in Terms of Various Variables. Electronic Journal of Social Sciences, 4(14), 115-127.

Cetintas, B., \& Genc, A. (2005). Opinions of German Teacher Candidates about Teaching Practice Lessons, Hacettepe University Faculty of Education Journal, 29, 75-84.

Ceyhan, A. A. (2004). Examining the hopelessness levels of prospective teachers who continue secondary education master's program without thesis. Anadolu University Journal of Social Sciences, 4(1), 91-102.

Cuceloglu, D. (1999). Man and his behavior, Remzi Bookstore, Istanbul, Turkey.

Deryakulu, D. (2011). Investigation of General Teacher Competencies of Kpss Educational Sciences Questions in Terms of Sub-Proficiency and Performance Indicators Related to Instructional Technology. Educational Technology Theory and Practice, 1, 1-23. https://doi.org/10.14689/issn.2148-2624.1.8c.1s.11m

Ehtiyar, Rv. (2017). The Effects of University Students' Attitude Towards the Future and Positive Future Expectations on Psychological Well-Being. Mediterranean Journal of Humanities, 2, 251-262. https://doi.org/10.13114/MJH.2017.361

Gustems-Carnicera J., Calderón C. \& Santacana M. F. (2017). Psychometric properties of the Life Orientation Test (LOT-R) and its relationship with psychological well-being and academic progress in college students. Revista Latinoamericana de Psicología, 49, 19-27. https://doi.org/10.1016/j.rlp.2016.05.001

Hunstiger, A., \& Koreik, U. (2006). Where does the DaF study lead? - To a graduate study in the DaF subject." Hiltraud Casper-Hehne, Uwe Koreik, Annegret Middeke (ed.) The restructuring of degree programs. Deutsch als Fremdsprache, 163.

Johnston, B. (2003). The shape of research in the field of higher education and graduate employment: Some issues. Studies in Higher Education, 28(4), 413-426. https://doi.org/10.1080/0307507032000122260

McKenzie, K., \& Schweitzer, R. (2001). Who succeeds at university? Factors predicting academic performance in first year Australian university students. Higher education research \& development, 20(1), 21-33. https://doi.org/10.1080/07924360120043621 
Monks, K., Conway, E., \& Dhuigneain, M. N. (2006). Integrating personal development and career planning: The outcomes for first year undergraduate learning. Active Learning in Higher Education, 7(1), 73-86. https://doi.org/10.1177/1469787406063216

Oskay, G. (1997). Examining the identity development levels of university students according to their faculties and departments. Hacettepe University Journal of Faculty of Education, 13, 63-73.

Polat, S. (2013). A qualitative research on the problems posed by paid teacher employment. Mehmet Akif Ersoy University, Journal of Faculty of Education, 28, 67-88.

Sezgin, F., \& Duran, E. (2011). The reflection of the Public Personnel Selection Examination (KPSS) on the academic and social life of the teacher candidates. Journal of Social Researches of Turkey, 153, 9-22.

Tuncer, M. (2012). According to the Views of Non-contracted Teachers' Evaluation of the Employment of Noncontracted Employed in Turkey. Gaziantep University Journal of Social Sciences, 11, 797 -818.

Uçman, H. (2006). Teacher employment styles of the Ministry of National Education, (Unpublished master's thesis) Ankara University Institute of Social Sciences, Turkey.

Wang, K. T., Slaneya, R. B., \& Rice, K. G. (2007). Perfectionism in Chinese university students from Taiwan: A study of psychological well-being and achievement motivation. Personality and Individual Differences, 42, 1279-1290. https://doi.org/10.1016/j.paid.2006.10.006

Washizu, N., \& Naito, T. (2015). The emotions sumanai, gratitude, and indebtedness, and their relations to interpersonal orientation and psychological well-being among Japanese university students. International Perspectives in Psychology: Research, Practice, Consultation, 4(3), 209-222. https://doi.org/10.1037/ipp0000037

Yalcin, P. (2014). Professional Concerns of Prospective Teachers Enrolled in English, French and German Teaching Departments. Hacettepe University Journal of Faculty of Education, 29, 256-266.

Yazici, H. (2009). Teaching profession, motivational sources and basic attitudes: a theoretical view. Kastamonu Journal of Education, 17, 33-46.

Yucel, M. S., \& Gocerler, H. (2018). German Teaching Area Knowledge Exam and German Departments. International Contemporary Education Research Congress (pp. 27-34), S1tk1 Kocaman University, Mugla, Turkey.

\section{Copyrights}

Copyright for this article is retained by the author(s), with first publication rights granted to the journal.

This is an open-access article distributed under the terms and conditions of the Creative Commons Attribution license which permits unrestricted use, distribution, and reproduction in any medium, provided the original work is properly cited. 